University of California, Hastings College of the Law UC Hastings Scholarship Repository

Faculty Scholarship

1980

\title{
Unraveling the Sagebrush Rebellion: Law, Politics and Federal Lands
}

John D. Leshy

UC Hastings College of the Law, leshyj@uchastings.edu

Follow this and additional works at: http://repository.uchastings.edu/faculty_scholarship

Part of the Natural Resources Law Commons

\section{Recommended Citation}

John D. Leshy, Unraveling the Sagebrush Rebellion: Law, Politics and Federal Lands, 14 U.C. Davis L. Rev. 317 (1980).

Available at: http://repository.uchastings.edu/faculty_scholarship/370

This Article is brought to you for free and open access by UC Hastings Scholarship Repository. It has been accepted for inclusion in Faculty Scholarship

by an authorized administrator of UC Hastings Scholarship Repository. For more information, please contact marcusc@uchastings.edu. 


\title{
Faculty Publications \\ UC Hastings College of the Law Library
}

\author{
Author: John D. Leshy \\ Source: $\quad$ University of California at Davis Law Review \\ Citation: $\quad 14$ U.C. Davis L. Rev. 317 (1980). \\ Title: $\quad$ Unraveling the Sagebrush Rebellion: Law, Politics and Federal Lands
}

Originally published in UNIVERSITY OF CALIFORNIA AT DAVIS LAW REVIEW. This article is reprinted with permission from UNIVERSITY OF CALIFORNIA AT DAVIS LAW REVIEW and University of California, Davis School of Law. 


\title{
ARTICLES
}

\section{Unraveling the Sagebrush Rebellion: Law, Politics and Federal Lands}

\author{
By JOHN D. LESHY*
}

\section{INTRODUCTION}

The "sagebrush rebellion" burst onto the Western scene in 1979, when the Nevada legislature began considering a bill to claim ownership of the "unappropriated" federally controlled public lands in the state. Since that measure was enacted in June $1979,{ }^{1}$ other Western states have passed similar bills. ${ }^{2}$ Thus the stage appears to be set for a legal test of continued federal management of much of the land in the West.

Dissatisfaction in Nevada with federal policies goes back at least as far as 1861, when the young Mark Twain accompanied his brother Orion to the newly created territory, where Orion

- Professor of Law, Arizona State University. A.B. 1966, Harvard College; J.D. 1969, Harvard Law School. The author was Associate Solicitor for Energy and Resources in the U.S. Department of the Interior from 1977 to 1980.

Ch. 633, 1979 Nev. Stats. 1362.

- Ariz. Rev. Stat. AnN. §§ 37-901 to -909 (West Supp. 1980); N.M. Stat. AnN. § 19-15-9 (Supp. 1980); Utah Code ANN. § 65-11-1-9 (Supp. 1980); Wash. Rev. Code § 79.80.020 (Supp. 1980); Wyo. Stat. § 36-12-10 (Supp. 1980). The Arizona bill became law after the legislature overrode the Governor's veto. The California legislature has taken a more modest approach. It has directed various state agencies to study the legal basis and financial implications of transferring federal lands managed by the Bureau of Land Management to the state. The study is to be completed by January 1,1982 . The bill, which became law without the Governor's signature, also authorizes the Attorney General to take such action as the legal analysis shows is appropriate. Ch. 831, \& 2, 1980 Cal. Legis. Serv. 2636 (West) (to be codified at Cal. Pub. Res. Code $\$$ 6201.5); see note 34 infra. 
had been appointed Secretary to the territorial government. Twain poked fun at the inability of the distant federal bureaucracy to govern an area 2,500 miles away. ${ }^{3}$ For example, he described the difficulty of obtaining sufficient federal money to pay for running the territorial government. The Secretary's instructions were to print the territorial legislature's journals at a particular cost. Things being expensive in the territory, this could not be done, so the Secretary entreatied his superiors in Washington for an increase, calling attention to the fact that

even hay was two hundred and fifty dollars a ton. The United States responded by subtracting the printing bill from the Secretary's suffering salary-and moreover remarked with dense gravity that he would find nothing in his "instructions" requiring him to purchase hay!

Nothing in this world is palled in such impenetrable obscurity as a U.S. Treasury Comptroller's understanding. The very fires of the hereafter could get up nothing more than a fitful glimmer in it."

But Washington was not the only object of Twain's acerbic pen. The first Nevada territorial legislature also received his jibes:

That was a fine collection of sovereigns, that first Nevada legislature. They levied taxes to the amount of thirty or forty thousand dollars and ordered expenditures to the extent of about a million. Yet they had their little periodical explosions of economy like all other bodies of the kind. A member proposed to save three dollars a day to the nation by dispensing with the chaplain. And yet that shortsighted man needed the chaplain more than any other member, perhaps, for he generally sat with his feet on his desk, eating raw turnips, during the morning prayer.

The legislature sat sixty days, and passed private toll road franchises all the time. When they adjourned it was estimated that every citizen owned about three franchises, and it was believed that unless Congress gave the territory another degree of longitude there would not be room enough to accommodate the toll roads. The ends of them were hanging over the boundary line everywhere like a fringe. ${ }^{\circ}$

Twain's observations foreshadowed the differences in perception which are reflected in rhetoric heard today about the sagebrush rebellion. Does it represent a genuinely inspired effort to replace distant, inefficient and unresponsive federal land man-

s M. Twain, Roughing It 129 (The Limited Editions Club, 1972).

4 Id. at 131.

s Id. at 132-33. 
agement with better, local governmental control? Or is it instead merely a land grab, with states fronting for certain interest groups who seek exclusive rights to exploit the resources of these lands free from any regulation? ${ }^{6}$ I will address some of the rebellion's political implications in the second part of this paper. First, however, since its proponents assert that the rebellion has a legal underpinning, its legal basis needs some scrutiny.

\section{The Rebellion's Legal Basis}

The rebels' claim is based directly on the constitutional provision for the admission of new states and its delineation of Congress' power over federal property. ${ }^{7}$ In effect, the rebels are saying that the question whether the federal government should retain ownership of lands after states are created out of territory acquired from foreign sovereigns is not really open to debate, because it was resolved by the founding fathers in favor of the states nearly two centuries ago.

\section{A. The "Equal Footing" Doctrine}

Particularly, the rebels construe the so-called "equal footing" doctrine ${ }^{8}$ - which allows that all states are admitted to the

- See, e.g., Boly, The Sagebrush Rebels, New West, Nov. 3, 1980, at 17; Hornblower, The Sagebrush Revolution, Washington Post, Nov. 11, 1979, at E1; Seldner, The Sagebrush Rebellion, NAT'L L.J., Sept. 1, 1980, at 1; Shay, The Sagebrush Rebellion, Srerra, Jan./Feb. 1980, at 29; Starnes, The Sagebrush Rebellion, Outdoor LIFE, Mar. 1980, at 101; Trueblood, They're Fixing to Steal Your Land, Findd \& Stream, Mar. 1980, at 40; Volek, Sagebrush Rebellion Heads for Courts, Western L.J., Nov./Dec. 1979, at 1; The Angry West vs. the Rest, Newsweek, Sept. 17, 1979, at 32.

7 U.S. Const. art. IV, $\S 3$. The rebels have not yet filed suit directly challenging federal title, but their legal arguments can be gleaned from several sources. Among these are the Nevada law itself, $\S 2$ of which contains a rather detailed recitation of the legal grounds for the claim, ch. $633,1979 \mathrm{Nev}$. Stats. 1362; briefs filed by the State of Nevada in an action against the Secretary of the Interior, challenging his withdrawal (later rescinded) of certain public lands in Nevada from Desert Land Act entry, Nevada v. Andrus, No. R-780077 (D. Nev., filed Apr. 25, 1978), and numerous statements by Nevada officials and other rebel spokespersons reported in various publications such as those cited in note 6 supra.

"The "equal footing" doctrine has been applied by the Supreme Court as a constitutional doctrine, even though it is not found in the text of the Constitution. See, e.g., Skiriotes v. Florida, 313 U.S. 69 (1941); Coyle v. Oklahoma, 221 U.S. 559 (1911); Escanaba Co. v. Chicago, 107 U.S. 678, 688-89 (1882). See also 
Union on an equal footing with each other-to require that all states be treated alike as far as federal retention of lands within their borders after statehood. The rebels read Supreme Court decisions applying the doctrine nearly a century-and-a-half ago ${ }^{\circ}$ as meaning that, because the federal government had no original landholding in the thirteen colonies, all states admitted since have ipso facto succeeded to ownership of all federal lands. Therefore, the rebels argue, all states are (and perforce, always have been) entitled to all the public lands within their borders merely by virtue of their admission into the Federal Union.

Cloaking such an argument in constitutional garb is not entirely new. In 1828 Governor Edwards of the then relatively new state of Illinois, arguing against an older state proposal to limit the sales of public lands in newer states, maintained that the federal government had no constitutional power to exercise control over public lands in a state after its admission into the Union. ${ }^{10}$ His own state legislature, along with those of several other then "Western" states-among them Alabama, Indiana, Louisiana and Missouri-made essentially the same argument between 1828 and $1833 . .^{11}$ But the argument, though constitutional in expression, took the form of petitions to congressional representatives, not to the courts. And so it was a century later when Governor Dern of Utah repeated Governor Edwards' argument while testifying before Congress on President Hoover's proposal to turn unappropriated federal lands, minus the mineral rights, over to the Western states. When pressed on the

P. Gates, History of Pubuc Land Law Development 73-74 (1968), for the background of the relevant constitutional provisions. Congress has traditionally admitted new states by statutes which provide for admission "on an equal footing with the original states in all respects whatever. . . ." See, e.g., Act of June 1, 1796, ch. 47, 1 Stat. 491, admitting Tennessee in 1796. See also Note, The Property Power, Federalism and the Equal Footing Doctrine, 80 Colum. L. REv. 817 (1980). For differing views of the equal footing doctrine as it relates to state and federal landholdings, particularly of lands on the outer continental shelf, compare Clark, National Sovereignty and Dominion over Lands Underlying the Ocean, 27 TEx. L. REv. 140 (1948) and Hanna, Equal Footing in the Admission of States, 3 BAylor L. REv. 519 (1951); with Hardwicke, Illig \& Patterson, The Constitution and the Continental Shelf, 26 TEx. L. REv. 398 (1948); and Patterson, The Relation of the Federal Government to the Territories and the States in Landholding, 28 TEx. L. REv. 43 (1949).

- E.g., Pollard v. Hagan, 44 U.S. (3 How.) 212 (1845).

10 P. Gates, supra note 8 , at 9.

11 Id. 
point whether this was a legal claim, however, Dern conceded that while it was "equitably true," it was "not legally true."18

Governor Dern's acknowledgment that the states' remedy was political and not legal apparently reflected a consensus on the point, for until the current rebellion, no one ever contemplated, so far as I know, a direct appeal to the judiciary. No state has mounted such a direct and far-reaching challenge to federal title to uplands (as opposed to the shores and beds of navigable waters) in the history of the republic. But now, nearly two centuries after ratification of the Constitution, Nevada and the other rebels seek to turn the states' political argument, based on equity and traditionally addressed to Congress, into a legal argument-and what is more important, a constitutional argument-addressed to the courts.

It is noteworthy that the rebels' resort to the courts is the only new wrinkle in what is otherwise an old debate, for it illustrates that the rebellion is just another in a series of attempts to wrest control from the federal government of vast amounts of public lands. ${ }^{13}$ The question of who should own and benefit from the

12 Granting Remaining Unreserved Public Lands to the States: Hearings on H.R. 5840 Before the House Comm. on the Public Lands, 72d Cong., 1st Sess. 15 (1932) [hereinafter cited as $H$. Public Lands Hearings]. Governor Dern went on: "The original Thirteen States received all their lands, and we feel if we were admitted on an equal footing we should have all our lands. Of course, that is not the law." Id.; see Hearings on S. 17, 2272, and S. 4060 Before the Senate Comm. on Public Lands and Surveys, 72d Cong., 1st Sess. 31-32 (1932) [hereinafter cited as S. Public Lands Hearings]. Other witnesses at these hearings referred explicitly to Pollard v. Hagan, 44 U.S. (3 How.) 212 (1845), for support, but there was also recognition that later Supreme Court decisions had limited its effectiveness. See, e.g., S. Public Lands Hearings, supra this note, at 68, 150 (Statement of Perry W. Jenkins); H. Public Lands Hearings, supra this note, at 74-75, 108-13 (Statement of Francis C. Wilson).

1s As with the current rebellion, these earlier attempts were a reaction to federal retention of land on a more or less permanent basis and the increasing imposition of regulatory controls on activities on those lands. Accounts of such efforts in 1891 and 1930 are found in P. GaTES, supra note 8, at 647-50 and $522-29$, respectively. There was also an effort in 1912. See S. Dana \& S. Fairfax, Forest and Range Policy 104-05 (2d ed. 1980). Some of the rhetoric employed in these earlier attempts is also strongly reminiscent of the current debate. For example, proponents of transfers of federal grazing lands in 1948 described federal policies as "arrogant, bigoted, and tyrannical," "void of respect of law or customs of our land or the rights and feelings of other people;" and federal management as "unreasonable, domineering and bureaucratic." See B. DeVoto, Sacred Cows and Public lands, 197 HARPER, July 1948, at 44- 
federal public lands is one which Congress has repeatedly addressed since the nation's founding. Indeed, the very formation of our constitutional government was threatened for a time by the question whether there would be any federal lands at all, or whether the original colonies would hold onto their "Western" land claims. ${ }^{14}$ Even after this question was decided, Congresses in the first century of the country's existence spent an extraordinary amount of time wrestling with the issue, mostly because public lands then provided a major source of federal revenue and, along with national defense, occupied a central part of the limited role played by the national government during that period.

In arguing about how to manage and dispose of these federal lands, states took sides in Congress based on their particular self-interests. The older states usually argued, with some success, for a share of the revenue of the public lands, contending that it took the blood and taxes of the entire nation to secure the lands into which the nation expanded after independence. The newer states argued, with measurably greater success (both in attaining statehood and later), that they needed land to grow and prosper, and federal aid to encourage settlement and exploitation of the natural resources within their borders. The accommodations Congress fashioned between the interests of older and newer states were reflected in numerous laws providing for management and disposal of federal lands. ${ }^{15}$ These accommodations allowed newer states to obtain title to sizeable amounts of federal public lands and the transfer of other federal lands into private hands for settlement and development. ${ }^{16}$ Once expansion crossed the 100th meridian beginning in the middle of the 19th century, the new states in the true arid "West" argued for and

55. See also B. DeVoto, The West Against Itself, 194 HARPERS, Jan. 1947, at 113; Easy Chair, 196 HARPERs, January, May 1948, at 28-31, 441-44; Easy Chair, 194 HARPERs, June 1947, at 543-46; Easy Chair, 194 HarPers, Jan. 1947, at 45-48. See also P. Gates, supra note 8, at 627-34; D. Mann, The Politics or Water in ARIzona 154 (1963).

14 "Western" in this context meant, of course, in and immediately west of the Appalachians. Maryland, one of the thirteen original colonies without such land claims, led the fight to have those colonies with such claims cede them to the national government. It refused to ratify the Articles of Confederation until cession was underway. See generally P. Gates, supra note 8, at 49-57.

16 See generally P. Gates, supra note 8, passim.

16 Id. at 121-26, 223-24, 236-38, 245-47. 
obtained, in addition to the above, a special share of the revenues generated by the resources of those lands retained in federal ownership and special programs to provide aid for settlement. ${ }^{17}$

More important for our purposes, this issue was also raised as each new state was proposed for admission. Then, too, political bargaining took place in the Congress over the terms of admission, and the granting or retention of federal lands was an important part of each statehood negotiation. The bargains struck over admission varied with time, local conditions and the politics of the moment, ${ }^{18}$ and thus not all new states received identical land grants for identical purposes. ${ }^{19}$ For example, Nevada was granted a variety of federal lands for various purposes at statehood. ${ }^{20}$

${ }^{17}$ See, e.g., the Desert Land Entry Act of 1877, ch. 107, 19 Stat. 377 (codified at 43 U.S.C. $\$ \S 321-323$ (1976)); the Carey Irrigation Act, ch. 301, 28 Stat. 422 (codified at 43 U.S.C. $\$ 641$ (1976)); and the Reclamation Act of 1902, ch. 1093, 32 Stat. 388 (codified in scattered sections of 43 U.S.C.), all of which applied only to specified Western states.

18 See, e.g, P. Gates, supra note 8, at 285-318; U.S. Public Land L. Rev. Comm'n, One Third of The Nation's Land 244 (1970) [hereinafter cited as PLLRC REPORT]. For example, Nevada was admitted in 1864 despite the fact that its population (about 7,000 ) was much smaller than any other state admitted previously. The Republicans in Congress, fearing that the presidential election that year might be decided by the House, wanted to add anti-slavery states to the union to improve Lincoln's chances by stacking the House with states that were expected to favor his reelection. See E. Bushnell, The Nevada Constitution: Origin AND Growth 29-30 (1965). They also wanted to bolster ratification of the 13th, 14th and 15th amendments to the Constitution. See Libecap, Government Support of Private Claims to Public Minerals: Western Mineral Rights, 53 Bus. Hist. Rev. 364, 371-72 (Aug. 1979).

10 Appendix C to P. Gates, supra note 8, at 804-06, and PLLRC REPort, supra note 18, at 244, show the total area of federal land grants to states. Nevada eventually received a total of $2,725,666$ acres, which was slightly less than many other states because of a later downward adjustment, initiated at $\mathrm{Ne}$ vada's request, from the nearly 4 million acres it was granted at statehood. See note 20 infra. States admitted more recently received larger grants. For example, Arizona and New Mexico, admitted in 1912, received 12.8 and 10.5 million acres, respectively. Act of June 20, 1910, ch. 310, 36 Stat. 557. Alaska, admitted in 1959, received selection rights to over 103 million acres. Pub. L. No. 85-508, 72 Stat. 339 (1958); see note following 48 U.S.C. § 21 (1976).

${ }^{20}$ The statehood act granted Nevada 12,800 acres for public buildings, 12,280 acres for a penitentiary, and sections 16 and 36 within every township to be used for school purposes. Act of March 21, 1864, ch. 36, 13 Stat. 30. In 1866, Congress expanded these grants to include 500,000 acres for "internal 
But that part of the statehood compacts dealing with lands was not purely one-sided. For example, some of Nevada's statehood land grants were, like those of several other states, imbued by Congress with a trust requiring the lands to be administered by the state for certain purposes. ${ }^{21}$ In addition, they embraced the retention of federal land in federal ownership as well as the grant of federal land to new states, for in agreeing to admit states, Congress wanted, bargained for and received final say

improvements," 46,080 acres for a university and 90,000 acres for a school of mines. It also singled Nevada out for special favorable treatment in selecting and disposing of these lands. Act of July 4, 1866, ch. 166, 14 Stat. 85. Two years later Congress granted Nevada additional land selection privileges. Act of June 8,1868 , ch. 55,15 Stat. 67 . In 1880, Congress approved Nevada's request to exchange its "in place" grant of sections 16 and 36 (totaling $3,904,746$ acres) for 2 million acres which it could select wherever the land appeared to be most valuable. Act of June 16, 1880, ch. 245, 21 Stat. 287. See generally P. Gatres, supra note 8, at 309-11.

21 See note 20 supra; PLLRC RePORT, supra note 18, at 247-48; and statutes collected in Dunipace, Arizona's Enabling Act and the Transfer of State Lands for Public Purposes, 8 ARIz. L. REv. 133, 134 n.7 (1966) and accompanying text. Not the least of the rebels' legal problems, explored more thoroughly in the text accompanying notes 24-76 infra, is the fact that the Supreme Court has twice unanimously upheld such restrictions. Lassen v. Arizona ex rel. Ariz. Highway Dep't, 385 U.S. 458 (1967); Ervien v. United States, 251 U.S. 41 (1919). See also United States v. Swope, 16 F.2d 215 (8th Cir. 1926); United States v. 112.2 Acres of Land, 293 F. Supp. 1042 (E.D. Wash. 1968), aff'd per curiam, 435 F.2d 561 (9th Cir. 1970). If the United States lacked constitutional authority to retain federal lands after statehood, it would seem equally to lack the authority to condition those grants it made to the states at statehood.

It is also interesting to note that Arizona, which has adopted a sagebrush rebellion statute over the Governor's veto, once asked Congress to amend its statehood enabling act to lift certain restrictions on the sale or lease of state lands. See Dunipace, supra this note, at 137-40. Although Arizona's attempt initially failed and was subsequently withdrawn, Congress sometimes has acted after statehood to revise the purposes for which and conditions on which these statehood land grants were made, or consented to amendments to a state's constitution changing the management of these lands. See, e.g., Act of May 13, 1968, Pub. L. No. 90-304, 82 Stat. 120 (lifting restriction in Ohio statehood act which required state to obtain consent of township inhabitants before sale of state school grant lands in township, and to invest proceeds for use in schools in that township); PLLRC REPORT, supra note 18, at 247-48; Shiner, State Mineral Leases on Arizona's School Lands, 15 ArIz. L. REv. 211, 218-22 (1973). See also Note, Administration of Grazing Leases of State Lands in New Mexico: A Breach of Trust, 15 Nat. Resources J. 581, 584-89 (1975). For a historian's often critical account of state administration of granted lands, see P. Gates, supra note 8, at 336-40. 
over the lands retained in federal ownership. Nevada, like most states admitted before and all states (except Hawaii) admitted since, therefore agreed as a condition of statehood to disclaim forever "all right and title to the unappropriated public lands lying within said territory, [which lands] shall be and remain at the sole and entire disposition of the United States."22

Nevada and the other states officially endorsing the sagebrush rebellion have not sought to reopen these statehood compromises worked out in the Congress. Thus they have, formally at least, turned their backs on the well established practice of seeking solutions through the political process, of trying to persuade other states to work through their congressional representatives to secure state or private ownership of more federal lands. ${ }^{23}$ Instead, they have opted to rely on judicial activism, to

22 Act of March 21, 1864, ch. 36, 13 Stat. 44. For a discussion of similar provisions in other statehood acts, see P. Gates, supra note 8, at 288-318. The congressional practice of retaining control over federal lands after statehood stems from the extension by the first Congress under the new Constitution of the Northwest Ordinance of 1787. Act of August 7, 1789, ch. 8, 1 Stat. 50. Article IV of the Ordinance provided that the "legislatures of those ... new States, shall never interfere with the primary disposal of the soil by the United States in Congress assembled, nor with any regulations Congress may find necessary for securing the title in such soil to the bona fide purchasers." Id. at 52; see P. Gates, supra note 8 , at 288.

${ }^{28}$ One of the several ironies of the sagebrush rebellion is that the rebel states have discarded the political process-on which they have relied for so long-at a point when their political power in Congress has never been greater. This power has inexorably increased over the years, first with the admission of the Western states and more recently because the population has grown in much of the West faster than in the nation as a whole. For example, 11 Western states (excluding California and Hawaii, but including Alaska) have $22 \%$ of the votes in the U.S. Senate but only $7 \%$ of the nation's population. Bureau of the Census, U.S. Dep't of Commerce, Statistical Abstract of the United States 1979 , at 14 . The population of the 13 Western states grew by $15.8 \%$ from 1970 to 1977 , whereas the nation as a whole grew only by $6.4 \%$. Id. at 15 . See generally Wechsler, The Political Safeguards of Federalism: The Role of the States in the Composition and Selection of the National Government, 54 Colum. L. REv. 543 (1954). One commentator recently suggested that a cause of the rebellion is the West's "ineffectiveness" in Congress. Note, The Sagebrush Rebellion: Who Should Control the Public Lands?, 1980 Utak L. Rev. $505,509-10$. While this may be the rebels' perception, an argument can easily be made for the opposite conclusion, see, e.g., note 82 and accompanying text infra, and even this commentator concedes that Western congressmen "wield significant power in the formulation of public land legislation . . . 1980 UTAH L. REv., supra this note, at 533. 
have the courts rather than Congress recognize and enforce their claim of title.

Before testing the rebels' claim in light of the evolution of constitutional interpretation since Pollard $v$. Hagan, ${ }^{24}$ let us examine the implications of accepting the rebels' argument. The first inquiry might be, assuming that the states have a good "equal footing" claim, to determine the appropriate remedy to cure the constitutional defect. Although the relief the rebels call for is title to at least some $e^{25}$ federal lands retained after statehood without disturbing statehood itself, this result is not selfevident.

The rebels apparently seek to explain away the states' statehood promise not to claim title to federal lands as being based on a misunderstanding-shared by the states and the Federal Congress-about the federal power (or lack of it) to require such a promise from the states. Because the federal government lacked the constitutional authority to retain lands in a state after statehood, the rebels argue, the states' promise should be disregarded. But the promise not to claim retained federal lands was an important part of each statehood bargain which, the Supreme Court has often observed, is akin to a private contract. ${ }^{26}$ If ordinary contract law principles are applied to these statehood contracts, then the contract may be set aside if it rests on a mutual mistake. ${ }^{27}$ Nevada and the other rebel states may, in other words, find themselves once again territories if their legal arguments succeed. ${ }^{28}$

\footnotetext{
24440 U.S. (3 How.) 212 (1845).

28 See notes 30 \& 34 and accompanying text infra.

26 See, e.g., Andrus v. Utah, 446 U.S. 500, 507 (1980). ("As Utah correctly emphasizes, the [statehood] school land grant was a 'solemn agreement' which in some ways may be analogized to a contract between private parties."). The court also relied on the analogy to "private contract remedies." Id. at 508. Justice Powell maintained that the statehood agreement was a "bilateral compact." Id. at 523 (Powell, J., dissenting). See also Stearns v. Minnesota, 179 U.S. 223, 249-50 (1900) ("The State . . . accepted the trust created by the act of Congress. Acceptance by a trustee of the obligations created by the donor of a trust completes the contract."); United States v. Morrison, 240 U.S. 192, 20102 (1916); Cooper v. Roberts, 59 U.S. (18 How.) 173, 177-79 (1855); cases cited in note 21 supra.

27 Restatement of Contracts $§ 502$ (1932).

20 The Supreme Court has occasionally ignored promises by new states at statehood where they were determined to embrace subjects inappropriate for federal concern, Coyle v. Oklahoma, 221 U.S. 559, 573 (1911) (state promise
} 


\section{Assuming Nevada and the other rebellious states are entitled}

not to move the state capitol for a period of years), or where they did not modify the already existing legal rights of the states. Pollard v. Hagan, 44 U.S. (3 How.) 212, 224, 229 (1845) (Alabama's promise not to claim title to "waste or unappropriated lands" within its territory was irrelevant because it automatically succeeded to title to beds and shores of navigable waters under equal footing doctrine at statehood, since the original colonies held title to such lands (citing Martin v. Waddell, 41 U.S. (16 Pet.) 367, 410 (1842)). See also United States v. Texas, 339 U.S. 707, 715-20 (1950), in which the equal footing doctrine was applied to vest title to offshore submerged lands in the United States because the original states did not have title to these lands, even though the federal government had agreed at statehood to allow Texas to retain "vacant and unappropriated public lands lying within its limits." Res. of March 1, 1845, J. Res. 8, 5 Stat. 797, 798. Such decisions can be construed to give the rebels some refuge from the argument that rebel states should revert back to territories, but other decisions have enforced such statehood promises to lands other than the beds and shores of navigable waters or offshore submerged lands. See cases cited in notes 21 \& 26 supra; $c f$. Gibson v. Chouteau, 80 U.S. (13 Wall.) 92 (1871), in which the Court expanded on the suggestion in Pollard that statehood promises merely underscore Congress' pre-existing plenary constitutional power over the public domain:

No state legislation can interfere with [the] right [of Congress to control the public domain] or embarrass its exercise; and to prevent the possibility of any attempted interference with it, a provision has been usually inserted in the compacts by which new States are admitted into the Union, that such interference with the primary disposal of the soil of the United States shall never be made.

Id. at 99. This case was also apparently the first to recite what has become ritual in Supreme Court decisions construing the Property Clause; viz., that Congress' power over the public lands is "subject to no limitations." Id. See text accompanying notes 68-69 infra.

The Supreme Court has also considered the "equal footing" doctrine as support for construing provisions in statehood enabling acts that navigable waters in the new states shall be "common highways and forever free" not to express congressional intent to prohibit a state from authorizing bridge construction obstructing such waters. Willamette Iron Bridge Co. v. Hatch, 125 U.S. 1, 9-10 (1880); Cardwell v. American River Bridge Co., 113 U.S. 205, 211-12 (1885). See also Escanaba Co. v. Chicago, 107 U.S. 678, 688-89 (1882) (similar result in interpreting "common highways and forever free" language in the Northwest Ordinance of 1787). The Court has also held that a statehood act disclaimer of any state right or title to lands or other property held by natives (or by the United States in trust for natives) did not evidence congressional intent to oust state law entirely, and accordingly upheld the application of state law prohibiting the use of salmon fishing traps by non-reservation Indians, where Congress had not given the Secretary of the Interior authority to promulgate regulations governing the Indians' exercise of aboriginal fishing rights. Organized Village of Kake v. Egan, 369 U.S. 60 (1962). In a companion case, however, the Court held that a statehood act disclaimer was effective to preserve the Secretary of 
to ignore their statehood promises and still remain states, the rebels' argument that title to federal lands passed to the states at statehood raises some fearsome possibilities. It threatens not simply federal ownership of public lands, but also other federal and private land titles throughout much of the country, including nearly all the West. For if the equal footing doctrine truly demanded that a state be granted all the public lands at statehood, the federal government plainly lacked the power to grant clear title to any of those lands to third parties after statehood. Thus the Nevada landowner who traces his or her title back to a patent granted by the federal government after the admission of Nevada in 1864 would find that title at best in jeopardy and at worst without value.

We may be confident that the proponents of the sagebrush rebellion had no intention of undermining private land titles when they embarked on their insurrection, but the effect of their argument seems undeniable. ${ }^{29}$ To be sure, the leading rebel, Nevada, officially claims title only to those federal lands now managed by the Bureau of Land Management (BLM) and not to all lands which were retained by the federal government after statehood in $1864 .^{30}$ But this is a limitation Nevada has imposed upon itself-not at all one that logic imposes on it. The equal footing argument is not so neatly cabined as the rebels would like it to be.

Assuming for a moment that the Supreme Court accepts the equal footing argument, the rebels' legal claim could be limited to lands now managed by BLM only if the states formally renounce or relinquish their constitutional right to other lands held or disposed of by the federal government after statehood. But this course is also not free from legal and practical difficulties. Legally, a state's power unilaterally to amend its statehood agreement not to claim public lands, without the consent of

Interior's authority (granted by Congress prior to statehood) to promulgate rules and regulations for the Metlakatla reservation to allow the Metlakatla Indians to use fish traps under certain circumstances, even when inconsistent with state law. Metlakatla Indians v. Egan, 369 U.S. 45, 57-59 (1962).

20 It is ironical that, although most rebels might call themselves conservatives, see Boly, supra note 6 , at 17,19 , their claims undermine land titles, stability of land tenure and investment security and they are relying on the courts to be activist-things for which liberals are more traditionally faulted.

so See Ch. 633, \& 3(2), 1979 Nev. Stats. 1362, which defines the lands claimed to exclude everything but lands now managed by the BLM. 
Congress, is doubtful. Such action might, as some states have previously recognized, ${ }^{31}$ be construed as breaching the statehood agreement, and thus could be held either ineffective or a repudiation of the statehood compact. ${ }^{32}$

Furthermore, it is likely such a renunciation would be held ineffective when, as in Nevada, it is attempted merely through simple legislation; an amendment to the state constitution is probably necessary. ${ }^{33}$ This would take considerable time, during which instability in property titles would, at a minimum, chill investment and could, at worst, bring to a halt all activity depending upon assurances of clear title.

Moreover, while most of the rebels have initially challenged title only to BLM lands, the temptation to expand their claims could prove irresistible. If a majority of a state legislature could today be persuaded to enact legislation claiming BLM lands, can we be sure that the legislature (or the electorate in voting on a constitutional amendment) will as easily relinquish identical claims to such areas as Indian reservations, national forests, national wildlife refuges, national parks and railroad grant lands? On the contrary, it seems equally reasonable to expect that constitutional success in claiming BLM lands would merely whet the rebels' appetite. Certainly to the extent that the rebellion is a manifestation of general dissatisfaction with federal policies, it may not be so easily confined to BLM lands. That this is not idle speculation is demonstrated by the fact that Wyoming's sagebrush rebellion statute lays legal claim to lands now managed by the Forest Service as well as BLM, and some states lay claim to water and minerals as well. ${ }^{34}$

s1 See note 21 supra.

32 See notes 26 \& 28 supra.

ss See note 51 and accompanying text infra. Although the situation might also be cured by federal constitutional amendment, this would be even more time-consuming and would give the Western states near-veto power if they chose to act as a bloc.

24 See Wyo. StaT. § 36-12-109 (Supp. 1980). The Wyoming law also expressly lays claim to "all water and mineral rights appurtenant not previously appropriated." Id. § 36-12-103. Similarly, the Utah statute claims "all minerals on or below the surface" of the land claimed. UTAH CodE ANN. $\S 65-11-1(3)$ (Supp. 1980). The Washington statute claims "all waters on and below the surface of the land and all minerals not previously appropriated." WASH. REv. CoDe ch. 79.80.020(1) (Supp. 1980). The Arizona and New Mexico statutes claim "minerals not previously appropriated" but are silent on waters. Ariz. Rev. Stat. AnN. § 37-902(c) (Supp. 1980); N.M. Stat. AnN. § 19-15-2(c) (Supp. 


\section{B. The Trusteeship Theory}

The rebels embellish their equal footing argument by postulating the existence of a trusteeship duty in the federal government to dispose of unappropriated public lands to the states or the private sector. Even assuming that federal retention of some lands after statehood is consistent with the founding fathers' intent, perpetual federal dominion over these lands is, the argument goes, constitutionally forbidden by the equal footing doctrine. The role of the United States pending such disposition is thus limited to that of "caretaker."

This argument accurately portrays the attitude that prevailed in the early decades of the nation's history. The policy of the national government was to hold most public lands essentially as trustee in fact, in the expectation that eventually title would be placed in state or private hands. Transfers out of federal ownership were designed primarily to spur settlement, growth and prosperity in the states, and secondarily to secure national benefits from such enterprises as the transcontinental railroads." This policy formed the basis of many statutes, ${ }^{36}$ but it was never fully or permanently incorporated into our jurisprudence as constitutional doctrine. ${ }^{87}$

Being for the most part an elaboration of the equal footing argument, the trusteeship idea suffers from most of the same problems. ${ }^{38}$ While it does not threaten private land titles trace-

1980). Because of the ambiguity in the phrase "not previously appropriated," one commentator has suggested that purported transfers may be ineffective. 1980 Utah L. REv., supra note 23, at 513-14 \& n.57.

so See, e.g., P. GATEs, supra note 8, at 362-68, 638-43, 650-51, 653-58, 695-96.

36 The more important laws are the Pre-emption Act of 1830, ch. 208, 4 Stat. 420; the Swamp Lands Act of 1850 , ch. 84,9 Stat. 519 (codified at 43 U.S.C. $\$ \S$ 982-984 (1976)); the Homestead Act of 1862, ch. 75, 12 Stat. 392 (codified at 43 U.S.C. §§ 161-163 (1976)); the Timber Culture Act of 1873; ch. 277, 17 Stat. 605; the Desert Land Entry Act of 1877, ch. 107, 19 Stat. 377 (codified at 43 U.S.C. $\S \S 321-323$ (1976)); the Timber and Stone Act of 1878, ch. 151, 20 Stat. 89 (codified at 43 U.S.C. $\S \S 311-313$ (1976)); the Carey Irrigation Act of 1894, ch. 301, 28 Stat. 422 (codified at 43 U.S.C. $\$ 641$ (1976)); and the Stock-Raising Homestead Act of 1916, ch. 9, 39 Stat. 862. Most of these statutes have since been repealed. See note 81 infra.

${ }^{37}$ See, e.g., P. Gates, supra note 8, at 566-67, 771. See also notes 54-66 and accompanying text infra; Hanna, supra note 8 , at $528,530-34$.

88 Arguing for enforcement of this alleged "trust" raises, in addition, a new batch of conceptual problems for the rebels. For example, if the federal government may satisfy its duty to dispose of its lands by transfer to private parties, 
able to post-statehood federal transfers (since such transfers are consistent with the notion that the federal government must dispose of these lands), it does threaten all federal holdings at statehood which never left federal ownership. If the United States retained unappropriated public lands after statehood in trust for eventual disposal, the terms of that trust would be violated if the United States instead reserved those lands for uses in the national interest. Yet millions of acres of unappropriated public lands were so reserved after statehood-for the military, Indian reservations, national forests, parks, wildlife refuges and a myriad of other uses-in all the Western states.

The Supreme Court has repeatedly upheld such reservations from legal challenge whether they were made by the Executive without express legislative authority ${ }^{89}$ or pursuant to statute, ${ }^{40}$ and even when the result was to displace grants to the states contained in various statehood acts. ${ }^{11}$ These latter decisions il-

may the states enforce that right, and may they obtain title in satisfaction of the assumed breach? Or is it sufficient merely for a court to order Congress to "dispose" of the lands as it sees fit? For example, could Congress satisfy this alleged duty by transferring large amounts of federal land to private entities with a view toward promoting domestic energy production? For a summary of the substantial energy resources on the federal lands, see 1980 UTAH L. REv., supra note 23 , at 511 .

A basic question raised by the rebels' theory is who decides when and on what basis the lands must be disposed: the Congress, the courts or the states? The rebels' answer seems to be that the states decide. Historically, of course, Congress has made those decisions, and has, moreover, conditioned such disposals on certain things; for example, reclamation and cultivation of the lands, 43 U.S.C. $\$ \S 164,329$ (1976), or, in the case of some railroad grants, eventual disposal to settlers. See, e.g., Act of April 10, 1869, ch. 26, 16 Stat. 46. Since such conditions operated in fact to limit the disposal of lands by the federal government, were they constitutional? Was the Supreme Court wrong in allowing title to certain Oregon and California Railroad grant lands to be revested in the federal government for breach of the conditions? See Oregon \& Cal. R.R. v. United States, 243 U.S. 549 (1917); Oregon \& Cal. R.R. v. United States, 238 U.S. 393 (1915). If the rebels are successful, could those who were denied patents to federal lands for failure to meet Congress' conditions now claim the conditions were unconstitutional, and gain title?

30 United States v. Midwest Oil Co., 236 U.S. 459 (1915).

10 Light v. United States, 220 U.S. 523 (1911).

11 See, e.g., Heydenfeldt v. Daney Gold \& Silver Mining Co., 93 U.S. 634, 639-40 (1876). Interestingly, this case involved the statehood grant to Nevada of sections 16 and 36 in every township to support common schools. Defendant perfected mining claims under federal law on certain lands which a federal survey subsequently revealed to be in section 16 . The state issued a patent to 
lustrate the legal box in which the rebels find themselves. Since the Supreme Court has held that the United States may displace even statehood grants of federal lands to a state by reserving them for other uses after statehood but prior to survey (so long as other lands are made available to the states), a fortiori the United States may set aside other lands it has retained at statehood for particular uses. Acceptance of the rebels' argument would therefore require overruling all such decisions and be tantamount to holding that most of the national forests, parks, monuments and wildlife refuges, military bases and Indian reservations were unconstitutionally created.

Nevada and her allies cannot draw a constitutional distinction

plaintiff in 1868, and six years later the federal government issued a patent embracing the same lands to defendant. The Supreme Court unanimously upheld defendant's patent, finding that until the survey was completed, Congress retained "absolute power" over the lands and could take action to defeat the statehood grant of those lands so long as the state was "compensated" by making other federal lands available. The Court observed:

By this means the state was fully indemnified, the settlers [mining claimants] ran no risk of losing the labor of years, and Congress was left free to legislate touching the national domain in any way it saw fit, to promote the public interests.

Id. at 640 . To the same effect is United States v. Wyoming, 331 U.S. 440, 453 (1946), where the Court pointed out the "necessity" of Congress' "reserving tracts of the public lands to accomplish such important purposes as preserving the national forests, and mineral resources, establishing public parks, and the like." See United States v. Morrison, 240 U.S. 192, 210 (1916); Wisconsin v. Lane, 245 U.S. 427, 432-33 (1918); cf. Andrus v. Idaho, 445 U.S. 715 (1980) (holding that the Carey Irrigation Act, ch. 301, 28 Stat. 422 (codified at 43 U.S.C. § 641 (1976)), did not prevent the Secretary of the Interior from "committing otherwise available parts of the public domain for any of the uses authorized under various statutes relating to the use and management of the public lands," even where the effect was to defeat a state application for the lands). See also Andrus v. Utah, 446 U.S. 500, 510-11 (1980) ("Prior to the 1930's, cases in this Court had made it perfectly clear that the Federal Government retained the power to appropriate public lands embraced within school grants for other purposes if it acted in a timely fashion."); Grisar v. McDowell, 73 U.S. (6 Wall.) 363, 380-81 (1867). In Grisar, the Court upheld, among other things, the President's authority to reserve lands in San Francisco from sale and set them apart for "public uses" over the claim of a landowner who succeeded to the city's title and relied on the city's inchoate pueblo right, derived from Mexican law applicable when the United States acquired the area which became California. The particular lands in question were first reserved by President Fillmore on November 5, 1850, two months after California became a state. Ch. 50, 9 Stat. 452 (1850). See also United States v. Midwest Oil Co., 236 U.S. 459, 471 (1915). 
between federal lands now managed by BLM and federal lands "reserved" after statehood for other purposes, because neither the equal footing doctrine nor Congress' constitutional power over federal property admits one. If the Constitution gives Congress the power to retain (or to authorize the Executive to set aside) federal lands after statehood for a military or Indian reservation, a park or a national forest, does it not also give Congress the power to retain and set aside BLM lands? And more specifically, if Congress has the power to retain federal lands in national forests for multiple-use management, does it not also have the power to retain federal lands for essentially the same kind of multiple-use management by BLM? This is, of course, exactly what Congress did in a series of enactments culminating in the Federal Land Policy and Management Act (FLPMA), a matter which is taken up in more detail below. ${ }^{42}$

The point is simply that the rebels cannot maintain this trusteeship argument and avoid undermining title to all land which has remained in federal ownership since statehood. Thus here, too, the states must-assuming their sole objective is ownership of BLM lands-formally renounce or relinquish their claims to all land other than that managed by BLM. The legal and practical difficulties inherent in that course have already been described.

\section{The Fate of the Claim in the Courts: Some Speculations}

It is the very scope of the rebels' claim which will prove its downfall. The constitutional doctrine argued for would undermine title to millions upon millions of acres of federal and nonfederal land. No court, no matter how inclined toward activism, can reasonably be expected to step out onto this slippery slope. ${ }^{4}$

4 See notes 78-83 and accompanying text infra.

18 The current contours of the debate inspired by the rebellion suggest either that the scope of the threat posed by the rebels' choice of legal argument is not fully understood or that few take it seriously as a legal matter. For the most part, holders of post-statehood mineral and homestead patents, desert land entries and railroad land grants, Indian tribes and others similarly affected have been uncommonly quiet. Some may actually be supporting the rebellion, even though it is, in a strictly legal sense, plainly against their selfinterest because it would cloud title to their land. More than anything else, perhaps, this demonstrates that this rebellion is no different from its many predecessors-a political movement ultimately seeking congressional action rather than judicial enforcement. 
This broad-brush assessment is fully supported by a closer analysis of the rebels' claim, for it reveals that the claim has several fundamental legal defects.

The first is an apparent problem with sovereign immunity-whether the United States has waived its immunity so as to be subject to the jurisdiction of the courts. Although the rebels' claim would seem to be covered by the limited-consentto-sue provision enacted by Congress in 1972 to allow adjudication of disputed titles to real property in which the United States claims an interest, ${ }^{44}$ that waiver is limited to actions commenced "within twelve years of the date upon which it accrued,"4s and actions are deemed to have accrued "on the date the plaintiff . . . knew or should have known of the claim of the United States." ${ }^{\prime 6}$ The courts have applied this language straightforwardly. ${ }^{47}$ The rebels can scarcely contend, given the obvious and continuous federal dominion over the public lands since statehood, to have been unaware of the federal claim of ownership, and while they have arguments to counter the seemingly harsh result that they are foreclosed by the limitation period, ${ }^{48}$

1428 U.S.C. $\S 2409 a$ (1976). The same act added a provision to 28 U.S.C. $\S 1346$ (1976) which vested the federal district courts with "exclusive original jurisdiction of civil actions under section 2409a . . .." Act of Oct. 25, 1972, Pub. L. No. 92-562, § 1, 86 Stat. 1176 (codified at 28 U.S.C. § 1346(f) (1976)).

4528 U.S.C. \& $2409 \mathrm{a}(\mathrm{f})$ (1976).

16 Id. Thus the key factor is knowledge of the federal claim, not the state claim. The obvious purpose, as with any such limitation period, is to avoid clogging the courts with stale claims and to ensure some stability in property titles. Cf. California v. Nevada, 447 U.S. 125, 132 (1980) (Nevada's claim to alter historically accepted boundary between it and California rejected because the time to object to inaccurate surveys "was when the surveys were drawn, not a century later." [citation omitted]).

${ }^{47}$ The courts have held that the 12-year period begins to run from the date the claim of the United States became known or should have become known, and not on the date the statute containing the waiver was passed. See, e.g., Grosz v. Andrus, 556 F.2d 972 (9th Cir. 1977); Hatter v. United States, 402 F. Supp. 1192 (E.D. Cal. 1975). The courts have dismissed actions where the federal claim of ownership was well known more than 12 years before the suit was brought. See, e.g., Hart v. United States, 585 F.2d 1280, 1284-85 (5th Cir. 1978); Grosz v. Andrus, 556 F.2d 972, 975 (9th Cir. 1977). The court in Hart pointed out that statutes which waive immunity of the United States are to be strictly construed, citing McMahon v. United States, 342 U.S. 25, 27 (1951). 585 F.2d at 1285.

48 The rebels may argue that their suit could not have been brought when the claim arose because sovereign immunity had not been waived. They could 
the outcome is far from clear.

A second and more serious problem involves the procedure by which Nevada now seeks to assert its claim. As previously noted, Congress' enabling act established as a condition of statehood that Nevada enact an "ordinance irrevocable" to "forever disclaim all right and title to the unappropriated public lands lying within the territory . . . ."40 Nevada met this condition by making the promise in an "ordinance" which, although not textually a separate article of the state constitution, is published with and was considered by the framers to be part of the constitution. ${ }^{30}$ Yet Nevada now seeks to repeal that promise by a mere act of its state legislature.

The statehood ordinance has been amended once since 1864, but by vote of the electorate - not by a majority of the legislature. $^{\text {s1 }}$ This precedent argues powerfully for similar treatment of the repeal of the statehood disclaimer against public land claims. Only when and if the state constitution is amended in this fashion would the Nevada claim seem ripe, ${ }^{62}$ assuming that

contend that they expected disposition of unappropriated public lands until Congress enacted the FLPMA in 1976; therefore, they should have until 1988 to file suit.

40 Act of March 21, 1864, ch. 36, 13 Stat. 30, 31; see text accompanying note 22 supra.

so See Oppicial Report of the Debates and Proceedings of the Constitutional Convention of the State of Nevada, at 50 (1866) [hereinafter cited as Nevada Debates and Procezedings]. But see Monnet, Violations of a State of the Conditions of Its Enabling Act, 10 Colum. L. Rev. 591, 605-07 (1910), which argues in the context of Coyle v. Oklahoma, 221 U.S. 559 (1911), then on its way to the Supreme Court, that such an "ordinance" ought not be considered part of a state constitution. See generally note 26 supra.

${ }^{* 1}$ In the 1956 general election, Nevada voters ratified an amendment proposed by the 1953 and 1955 legislatures which added the qualifying words "unless otherwise provided by the Congress of the United States" to the state's promise, contained in the same paragraph as the disclaimer regarding public lands, not to tax federal property in the state. See REs. 3, 1955 Nev. Stats. 926; Res. 9, 1953 Nev. Stats. 718.

\$2 See text accompanying notes 30-32 supra. The Washington Legislature apparently accepted this premise, for the part of its "rebellion" statutory package included proposing an amendment to the state constitution repealing the disclaimer, which was submitted to the electorate in November 1980 . S.J. Res. No. 132 (1980), referred to in WASH. REv. CoDE ch. 79.80 .901 (1980). Washington's voters rejected the amendment by a substantial majority, approximately 764,000 to 507,000 . Seattle Times, Nov. 5, 1980, at 1 . The necessity of repealing the statehood promise by constitutional amendment has been mandated by the Supreme Court where the state's statehood promise also disclaimed any juris- 
federal agreement to the change. is not necessary. This course has the additional practical advantage of having the state's electorate directly address the issue. ${ }^{.3}$

Nevada's claim also runs squarely into the teeth of a century of United States Supreme Court decisions in this area. As noted earlier, the rebels' argument is based principally on Pollard $v$. Hagan, ${ }^{\text {s4 }}$ in which the Court announced the rule that the states, rather than the United States, own the shores and beds of navigable water. Although the rebels construe the Court's opinion as lending support to their argument that the federal government could not permanently hold any land in a state after statehood,, the Court expressly decided only the ownership of the shores and beds of navigable waters. ${ }^{\text {sb }}$ More important, the Court in subsequent cases has consistently limited Pollard to its narrow holding and refrained from extending its reasoning to uplands.

These subsequent cases cover a broad range of subjects and permeate many aspects of state-federal relations, including such matters as federal power to enforce conditions placed on grants of land to a state at statehood, ${ }^{57}$ or to private parties after statehood; ;8 federal power to reserve lands in a state after statehood, ${ }^{, 9}$ even where the effect is to displace statehood grants; ${ }^{\circ 0}$ federal retention of title to the beds of non-navigable waters after statehood; ${ }^{61}$ federal power to grant or reserve the beds of

diction over Indian lands. McClanahan v. Arizona State Tax Comm'n, 411 U.S. 164, 175-78 (1973). See also note 21 supra.

ss See text accompanying notes $95-97$ infra.

o4 44 U.S. (3 How.) 212 (1845).

ss See, e.g., id. at 221, 223, 224, 228-29.

so Id. at 225, 229, 230. In historical context, Pollard v. Hagan, 44 U.S. (3 How.) 212 (1845), marks the highwater point for states' rights to federal lands. See Engdahl, State and Federal Power over Federal Property, 18 ARIz. L. REv. 283, 295-96 (1976).

or See cases cited in note 21 supra.

so See cases cited in note 38 supra.

so See cases cited in notes 39 \& 40 supra.

- See cases cited in note 41 supra.

-1 See, e.g., United States v. Oregon, 295 U.S. 1, 14, 26-29 (1935); United States v. Utah, 283 U.S. 64, 75 (1931); Brewer-Elliott Oil \& Gas Co. v. United States, 260 U.S. 77, 83-85 (1922); Oklahoma v. Texas, 258 U.S. 574, 583, 591 (1922); Donnelly v. United States, 228 U.S. 243, 260-64 (1913). For a thorough discussion of the decisional guideposts in this area, see Davis, State Ownership of Beds of Inland Waters-A Summary and Reexamination, 57 NeB. L. Rev. 665 (1978). 
navigable waters prior to statehood; ${ }^{62}$ federal power to impose conditions on the use of federal lands retained after statehood, or even to prevent occupation of and passage over such lands; federal power to build reclamation projects and subject them to reasonable conditions without interference by state law, ${ }^{84}$ and federal power to reserve waters in a state after statehood to benefit federal reserved lands. ${ }^{85}$ In none of these cases was there substantial disagreement by the Court on the extent of federal power, which the Court has consistently characterized as broadly as it has ever described any constitutional power. Indeed, the matter seemed so well settled three decades ago that Professor

o2 Shively v. Bowlby, 152 U.S. 1, 47-48, 58 (1894) (dictum, because the Court construed a pre-statehood federal grant to a private party not to include the bed of navigable water, and thus upheld the post-statehood grant of the bed by the state to a third party); United States v. Holt State Bank, 270 U.S. 49, 55 (1926) (same, no intent on part of United States to reserve bed of navigable lake to Indians prior to statehood); cf. Alaska Pacific Fisheries v. United States, 248 U.S. 78, 89 (1918) (congressional reservation in Alaskan territory of "body of lands known as Annette Islands" interpreted to include bed of adjacent navigable waters). See also United States v. Alaska 423 F.2d 764, 768 (9th Cir.), cert. denied, 400 U.S. 967 (1970) (upholding pre-statehood federal reservation of the bed of navigable water as part of the Kenai National Moose Range against state ownership claim based on the equal footing doctrine); Moore v. United States, 157 F.2d .760, 784 (9th Cir. 1946), cert. denied, 330 U.S. 827 (1947) (upholding federal reservation of bed of navigable waters prior to statehood for benefit of Indians to defeat state's attempt to apply its fish and game laws to the area).

os See, e.g., McKelvey v. United States, 260 U.S. 353, 359 (1922); Utah Power \& Light Co. v. United States, 243 U.S. 389, 405 (1917); Light v. United States, 220 U.S. 523, 536 (1911); Camfield v. United States, 167 U.S. 518, 524 (1897).

*4 Ivanhoe Irrigation Dist. v. McCracken, 357 U.S. 275, 294-95 (1958).

o6 Arizona v. California, 373 U.S. 546 (1963). This case is typical of the Court's approach. In rejecting Arizona's contention-explicitly derived from Pollard v. Hagan, 44 U.S. (3 How.) 212 (1845)_that the United States was without power to reserve waters in a state after statehood to benefit federal lands, the Court was curt:

But those cases involved only the shores of and lands beneath navigable waters. They do not determine the problem before us and cannot be accepted as limiting the broad powers of the United States to regulate navigable waters under the Commerce Clause and to regulate government lands under Art. IV, $\S 3$ of the Constitution. We have no doubt about the power of the United States under these clauses to reserve water rights for its reservations and its property.

373 U.S. at $597-98$. 
Hanna could write: "[T]he power of the nation to retain . . . ownership and control of public lands [after statehood] is so well settled that any citation of authority is superfluous."

It is not necessary to fathom the detailed steps of reasoning with which the Supreme Court justified the change in sentiment that led the more popularly responsive branches of the national government, the Congress and the Executive, to retain federal land for management in the national interest. ${ }^{67}$ Such changes have been found constitutionally justified without serious question for nearly a century. What is most relevant is the fact that it was done.

Thus the rebels seek to strip Congress of power over federal property that has been inexorably reinforced by a long line of Supreme Court decisions. In doing so, the rebels find themselves in an awkward position. It is not enough to argue simply that unanimous decisions as recent as the four-year-old Kleppe $v$. New Mexico ${ }^{68}$ - which once again ritually proclaimed that Congress' power over federal property was "without limitations" rebels must also convince the Court that the issue raised by New Mexico (and supported by amicus briefs from some of the states who have since joined the rebellion)-congressional power over wildlife management on the public lands-was the wrong issue, and that the real issue is ownership of the land itself. Although there might be room for doubt about whether the sweeping language of Kleppe will remain unscathed by future decisions, ${ }^{70}$ it would be truly startling for the Court to concede that the line of cases culminating in Kleppe-unbroken for many decades-was so wrongheaded.

The narrow holding of Pollard has survived for 135 years. ${ }^{71}$

Hanna, supra note 8, at 529.

67 The story of the movement for federal retention has been well told by many, including E. L. Pefrer, The Closing op the Public Domain (1951), and R. Robbins, Our landed Heritage (1942).

68 426 U.S. 529 (1976).

69 Id. at 539 (quoting United States v. City \& County of San Francisco, 310 U.S. 16, 29-30 (1940)).

70 See, e.g., Engdahl, supra note 55; Note, The Property Power, Federalism and the Equal Footing Doctrine, 80 Colum. L. REv. 817 (1980).

71 Although the holding has survived, the Supreme Court has nevertheless repeatedly held that the federal government retains a navigation servitude over the beds of navigable waters which can be exercised to extinguish rights to that 
But it, like those later cases making clear that the rule it announced does not extend further, is always subject to reexamination, extension or reversal. Indeed, all important constitutional issues may warrant periodic scrutiny in light of the country's growth and development. But change in constitutional interpretation seldom comes dramatically, with sharp reversals from previous doctrines; instead, there are gradual shifts as individual decisions chip away at those doctrines which prove over the longer term to be unsuited to the way the nation is evolving. ${ }^{72}$ Here, however, there is no indication that the Court's view of federal power over public lands might undergo the dramatic, almost unprecedented shift that the rebels will ask it to make. Moreover, the result the sagebrush rebels seek would necessarily involve more than a simple reworking of the allocation of power between the states and the federal government. It would go much further to undermine the very basis upon which most new states were admitted to the Union and toss aside many decades of reliance-by private citizens and states as well as the federal government-on the agreements made by each new state not to claim title to federal lands. Pollard might have been extended relatively easily to uplands in the middle of the last century, but to do so now would lead to chaos. It is nearly inconceivable that even the most activist, states'-rights-oriented court would dare embark on such a course now in the third century of our country's history, especially because the rebels have always had readily available a tried and true political, rather than constitutional, remedy for their alleged grievances.

For these reasons, even if the Supreme Court eventually addresses the issues, I would wager that not one member of that Court will give serious countenance to Nevada's argument, despite the fact that a majority has lately manifested sympathy toward states' rights positions in other areas. ${ }^{73}$ Rather, I would

property under certain circumstances without compensation. See generally Morreale, Federal Power in Western Waters: The Navigation Power and the Rule of No Compensation, 3 Nat. Resources J. 1 (1963); Comment, Navigation Servitude-the Shifting Rule of No Compensation, 7 LAND \& Water L. REv. 501 (1972).

72 The decisional history between Plessy v. Ferguson, 163 U.S. 537 (1896), and Brown v. Board of Education, 347 U.S. 483 (1954), is a good example. See, e.g., R. Kluger, Simple Justice 84-284 (1976).

${ }^{78}$ See, e.g., California v. United States, 438 U.S. 645 (1978); National League of Cities v. Usery, 426 U.S. 833 (1976). 
expect the Court to adopt the approach of its recent decision in United States $v$. Maine. ${ }^{74}$ In that case, the Court unanimously rejected eastern coastal states' arguments that they retained proprietary rights to the seabed beyond the three-mile marginal sea as successors to grantees of the Crown of England (and in the case of New York, to the Crown of Holland). The holding is not remarkable, since the Court had more than two decades earlier rejected a similar claim by California. ${ }^{75}$ What is noteworthy, however, is the Court's reluctance to disturb the expectations created in reliance on generally accepted rules with far-reaching implications:

It is apparent that in the almost 30 years since California, a great deal of public and private business has been transacted in accordance with those decisions. . . . We are quite sure that it would be inappropriate to disturb our prior cases, major legislation, and many years of commercial activity by calling into question, at this date, the constitutional premises of prior decisions. [The states here] have been on notice of the substantial body of authoritative law, both constitutional and statutory, which is squarely at odds with their claims ... [ [and they have not] been in the slightest misled. ${ }^{76}$

74420 U.S. 515 (1975).

${ }^{76}$ United States v. California, 332 U.S. 19 (1947). The effect of this holding was subsequently reversed by Congress in the Submerged Lands Act of 1953, 43 U.S.C. \& 1301 (1976), though, as the Supreme Court pointed out, Congress did not then repudiate the Court's decision that Congress had paramount authority over those lands; instead, the Act was "merely an exercise of that authority." United States v. Maine, 420 U.S. 515, 524 (1975).

${ }^{78}$ United States v. Maine, 420 U.S. 515, 527-28 (1975) (footnotes omitted). Justice White authored the opinion for a unanimous court (Justice Douglas not participating). Curiously, Justice Rehnquist, writing less than two years later for the majority in Oregon ex rel. State Land Bd. v. Corvallis Sand \& Gravel Co., 429 U.S. 363 (1977), did not cite and thus made no attempt to distinguish United States $v$. Maine in suggesting that, while substantive rules governing real property are "peculiarly subject" to the principle of stare decisis, that principle plays a "less important role" when the issue is "substantially related to the constitutional sovereignty of the states." Id. at 381. In Corvallis, a majority of six Justices overruled a three-year-old decision, Bonelli Cattle Co. v. Arizona, 414 U.S. 313 (1973), and decided that state rather than federal law should be applied to determine, between a state and a private party, who owned land which became part of the bed of a navigable river after statehood through a shift in the watercourse. Because the issue in Corvallis was so limited in scope, the approach of the Court to the much broader claim in United States $v$. Maine would seem to provide the better clue to how it would respond to an even more far-reaching question posed by the rebels. See also Leo Sheep Co. v. United States, 440 U.S. 668 (1979), where Justice Rehnquist, writing for 
It is difficult to imagine a more resounding death knell for the sagebrush rebellion as constitutional doctrine.

\section{The Sagebrush Rebellion as Policy and Politics}

Although it might be argued that the rebels have, by spurning the legislative for the judicial remedy, chosen to forego raising the ownership issue in Congress, at least a few congressmen have proposed to have that body address it. ${ }^{77}$ Therefore, let us briefly examine that issue on its policy, as opposed to its legal merits. The first thing to note is that only recently has Congress addressed the issue of federal public land policy once more, resolving it in favor of continued federal retention and management of most public lands, while at the same time setting forth uniform standards and procedures by which some lands may be sold.

If a single development may be said to have triggered the rebellion, in fact, it is Congress' enactment of the Federal Land Policy and Management Act of $1976 .{ }^{78}$ That Act was the culmination of a congressionally inspired re-evaluation of federal public land management given impetus by the report of the Public Land Law Review Commission (PLLRC) six years earlier. ${ }^{70}$ The PLLRC recommended express reversal of the presumption, reflected in numerous prior statutes, that there would be largescale disposals of the unappropriated public lands. While not closing the door entirely on future disposals, it concluded that "most public lands would not serve the maximum public interest in private ownership."

a unanimous Court (Justice White not participating), noted that the Court "has traditionally recognized the special need for certainty and predictability where land titles are concerned," and expressed unwillingness to "upset settled expectations" by finding a heretofore unrecognized reservation implied in a century-old federal grant of land to a railroad. Id. at 687-88.

${ }^{77}$ Bills introduced in the 96th Congress to transfer federal lands to the states included S. 1680, 96th Cong., 1st Sess., 126 Cong. REc. S 11657 (1979); and H.R. 7837, 96th Cong., 2d Sess., 126 Cong. Rec. H 6534 (1980). No hearings were held in either the House or Senate.

7843 U.S.C. \$§ 1701-1782 (1976).

70 PLLRC REPoRT, supra note 18. For a brief summary of prior detailed studies of the public lands, see P. Gatzs, supra note 8, at xi-xii.

so PLLRC REPORT, supra note 18, at 1. The Report found that, although the statutory disposal policy previously in effect had not been formally repealed, it had been rendered "ineffective." Id. It noted that passage of the Taylor Grazing Act in 1934, ch. 865, 48 Stat. 1269 (codified in scattered sections of 43 U.S.C.), had "ended the era of unrestricted entry" of the public lands, PLLRC 
The PLLRC's recommendation on federal retention was carried out in the FLPMA. That Act formally repealed nearly all disposal laws, substituting a general presumption of retention and a uniform provision for sales. ${ }^{81}$ It is especially worth noting, in the current climate of rebellion, that the primary proponents and shapers of both the PLLRC and the FLPMA were Westerners. ${ }^{82}$ The region that would most feel the impact of the law thus played the biggest role in writing it.

What, then, are we to make of the sudden rise of the sagebrush rebellion so soon after this latest national debate appeared to have determined, once and for all, that the bulk of the remaining public lands should be retained in federal ownership and managed in the national interest? Did the PLLRC and the Congress misread Western public sentiment on the issue so seriously that a grassroots "rebellion" spontaneously arose to protest this alleged "selling out" of Western interests? I think not. Instead, I suggest that the rebellion has several disparate roots which are not easily reconciled with each other, but which can

REPORT, supra note 18 , at 43 , and pointed out that its recommendation on disposal was in opposition to the 1930 recommendation of a presidential commission that remaining unappropriated public lands (but not mineral interests in these lands) be turned over to the states. Id. at 48. For an account of the 1930 proposal, see P. Gates, supra note 8, at 522-29; H. Public Lands Hearings, supra note 12; S. Public Lands Hearings, supra note 12.

${ }_{81}$ The sales provision is found at 43 U.S.C. $\S 1713$ (1976). The repealer provisions are not codified but are found at $\$ \S 702-706$ of the Act, 90 Stat. 2743, 2787-94 (1976). Various homestead and settlement laws were repealed effective Oct. 21, 1988, in Alaska; otherwise, the repeals were effective immediately. See $\S \S 702,703,90$ Stat. 2743, 2787-91 (1976). Section 102(a)(1), 43 U.S.C. § 1701(a)(1) (1976), states the policy of Congress that "the public lands be retained in Federal ownership, unless as a result of the land use planning procedure provided for in this Act, it is determined that disposal of a particular parcel will serve the national interest." See generally Anderson, Public Land Exchanges, Sales and Purchases Under the Federal Land Policy and Management Act of 1976, 1979 UTAH L. REv. 657.

${ }^{82}$ Fourteen of the nineteen signatories to the PLLRC Report were from Western states, including 11 of the 13 congressional members and 3 of the 6 presidentially appointed members. PLLRC REPORT, supra note 18, at iv. Fourteen of the seventeen FLPMA conferees were from the West. H.R. REP. No. 94-1724, 94th Cong., 2d Sess. (1976). See also note 23 supra; Wechsler, The Political Safeguards of Federalism, 54 Colum. L. REv. 543, 546 (1954). For a discussion of the background of the PLLRC's Report and its relationship to the FLPMA, see Muys, The Public Land Law Review Commission's Impact on the Federal Land Policy and Management Act of 1976, 21 ARIz. L. REv. 301 (1979). 
teach us several things about politics and values in the modern West.

First, the rebellion obviously feeds at the trough of national disaffection with government regulations and bureaucracy. With its extensive landholdings giving it a highly visible, pervasive presence throughout the West, the federal government naturally feels the brunt of anti-government feeling there. Moreover, the FLPMA goes well beyond mere retention of the public lands. It and other recent laws have placed new restrictions on the private exploitation of the public lands, especially their forage and minerals. ${ }^{83}$ As the reality of such restrictions has become apparent, those most affected-graziers and miners-have begun to chafe at this reduction in their freedom of exploitation. ${ }^{84}$ In this sense, the rebellion mimics earlier calls for transfers out of federal ownership by commodity interests threatened with regulatory constraints; indeed, it is difficult to read current rebel rhetoric without a strong sense of deja vú. ${ }^{8 s}$

Also at work here is the increasing realization that man's abilities to make nature over in his own image are not unbounded. Nautral limitations in the West, most obviously its aridness, have long been obstacles to development. But in many areas they have been, at least for the time being, successfully surmounted by man's ingenuity, ${ }^{86}$ often aided by federal

ss See, e.g., FLPMA § 302, 43 U.S.C. § 1732 (1976).

s4 To the extent graziers and miners are motivating forces behind the rebellion, its legal basis poses a considerable irony. Most livestock graziers and some miners own land whose title derives from post-statehood grants from the federal government, which could be jeopardized by judicial acceptance of the rebels' constitutional claim. See text accompanying notes 28-29 supra.

ss See note 13 supra for examples of the rhetoric employed in the 1948 "rebellion." See also S. Public Lands Hearings, supra note 12, at 158-59:

[I]nstead of being governed by laws, we are rapidly being ruled by bureau rules and regulations. .... [T] he Federal official in charge of forest, park, and Indian reservation is a member of bureau [sic] that makes rules and regulations. He enforces them as his fancy dictates, and is policeman, prosecuting attorney, judge, jury, and executioner within his domain.

(Statement of Thomas Maddock, attached to Statement of Perry W. Jenkins, representing the American Nat'l Livestock Assoc.)

${ }^{86}$ It should be noted that Nevada, the birthplace of the current rebellion, is not a paradigm of this idea, for most of the state never overcame its natural heritage of aridity. The principal reason that the federal government has retained more than $87 \%$ of the land in the state is not because the federal government refused to open its lands for development. Rather, relatively little 
funds. ${ }^{87}$ But now Westerners find themselves facing resource shortages which are not only fractious but, more important, appear to defy the solutions of the past. ${ }^{88}$ Part of the frustration provoked by that realization has undoubtedly tarnished the image of the federal government as problem-solver. ${ }^{89}$ At the same

land was homesteaded or otherwise reclaimed and cultivated to qualify for post-statehood federal land grants, because of outright lack of water or the prohibitive cost of bringing it to the land. For example, only about $3 \%$ of the 11 million acres transferred into private ownership in the Western states under the Desert Land Act between 1877 and 1977 was in Nevada; similarly, less than $1 \%$ of the more than 70 million acres transferred between 1917 and 1977 under the Stock-Raising Homestead Act was in Nevada. Bureau or LAND Management, U.S. Dep't of the Interior, Public Land Statistics 1977, at 10, 54, 55.

87 The program for reclamation of arid lands created by the Reclamation Act of 1902, ch. 1093, 32 Stat. 388 (codified in scattered sections of 43 U.S.C.), is perhaps the outstanding example. Pursuant to it, over $\$ 8.5$ billion has been spent by the federal government in developing water supplies in the Western states. U.S. Dep'T OF THE INTERIOR, 1977 Water AND LAND RESOURCe AccomPlishments-Summary Rep. 59 (1978) [hereinafter cited as 1977 Water]. One of the first projects built by the federal government under this Act was near Reno, and currently under federal construction is the nearly 200-million-dollar southern Nevada Water Project to supply Las Vegas with Colorado River water. Id. at 349.

88 Bernard De Voto, always a keen if acerbic observer of the Western scene, saw this trend unfolding more than a quarter of a century ago in describing Arizona's water problems: "Arizona is the first [but, implicitly, not the last] Western state to come within sight of an absolute limitation; a fiat of nature which says 'So Far and No Farther.'" DeVoto, "Boom or Bust," Collier's, Dec. 25, 1953, at 46. In Nevada as well, conflicts over scarce water supplies in the Reno area have given rise to more than a half dozen lawsuits involving cities, farmers, Indians, and federal and state governments. See, e.g., Pyramid Lake Paiute Tribe of Indians v. Morton, 354 F. Supp. 252 (D.D.C. 1973).

89 Two examples illustrate the point. First, the federal government has so far expended approximately $\$ 3$ billion to store and deliver Colorado River water. 1977 WATER, supra note 87, at 349. But in recent years the quality of Colorado River water has suffered, partially because of the heavy use these federal expenditures have made possible. Now the federal government finds itself spending well over half a billion dollars to maintain water quality 80 that it can continue to be used in this country and in Mexico. See, e.g., Colorado River Salinity Control Act, 43 U.S.C. \$§ 1571-1599 (1976), as amended by Pub. L. No. 96-336, 94 Stat. 1063 (1980). Second, although the giant undertaking to bring Colorado River water to central Arizona (the Central Arizona Project) was originally conceived to make new areas of the southwest desert "bloom," see N. Hundley, Water and The Wrst 159-64 (1975); R. Johnson, The Central Arizona Project 1918-1968, at 13-14, 16 (1977), now the project, under federal construction with a price tag approaching $\$ 2$ billion, is frankly designed 
time, ironically, the resources of federal lands are increasingly being viewed as providing a safety net to help solve local or regional problems in the West.90

Another factor is an idea long basic to the Western system of values - that man not only can but must exploit and tame nature into submission in order to survive and prosper in the sometimes harsh Western environment. Part of the FLPMA's regulatory scheme is designed to achieve environmental restoration and protection on all the public lands and, beyond that, to preserve parts of the public lands in their natural condition. ${ }^{91}$ This does not go down easily with those who, by experience or cultural inculcation, regard the natural environment as their enemy.

A fourth root of the rebellion is found in the greatly increased competition for public lands and resources. "Multiple use" is the well worn phrase which describes the fundamental management principle for most public lands in this country. ${ }^{92}$ Yet until recently, overt competition for use of specific areas of public lands was the exception rather than the rule. Livestock graziers, miners, lumbermen, hunters and fishermen generally coexisted peacefully, and few other demands were placed on these lands. Now, however, growing numbers of off-road vehicle fanciers, wilderness advocates, endangered species and other wildlife protectionists, white-water enthusiasts, cultural and archaeological re-

to "rescue" central Arizona from the consequences of a severe overdraft of the region's largely non-recharging groundwater supplies. Id. at 103, 231. Furthermore, despite Arizona Governor Osborn's 1948 prediction that the project would "forever end the recurring threats of water shortage that has [sic] plagued the area since man arrived," quoted in Jarvis v. State Land Dep't, 104 Ariz. 527, 534, 456 P.2d 385, 392 (1969) (McFarland, J., concurring), the overdraft is now so large that the water the project will bring to central Arizona represents only between $1 / 4$ and $1 / 3$ of the annual statewide overdraft, or about $2 / 3$ of the annual overdraft in Maricopa, Pinal and Pima counties, the principal areas to be served. Arizona Water Comm'n, Arizona State Water Plan, Phase I, Summary Inventory of Resource and Uses 31-35 (July 1975).

${ }^{\circ 0}$ For example, Congress recently authorized the pumping of groundwater under public lands in order to reduce the possibility that the water rights claims of the Ak-Chin Indian Community in Central Arizona would be satisfied from water now being used by non-Indians. See Act of July 28, 1978, Pub. L. No. 95-328, 92 Stat. 409.

O1 FLPMA § 603, 43 U.S.C. § 1782 (1976).

92 See, e.g., 16 U.S.C. $\S \S 529,531$ (a) (1976) (national forests); 43 U.S.C. $\S \S$ 1702(c), 1732(a) (1976) (BLM lands). 
source investigators, hikers, campers, skiers, photography buffs and rockhounds ${ }^{\theta 3}$ have combined with the sometimes increasing demands of more traditional users (especially those seeking to exploit domestic energy resources) to place unprecedented strains on the poor land managers who must give concrete meaning to the lordly dictate of "multiple use." Increasing competition inevitably means increasing regulation and red tape for all public lands users, most dramatically illustrated, perhaps, by the increasing need to require permits for foot access into wilderness areas. Needless to say, such regulation does not please those whose private pursuits are regulated in order that the public's resources may be preserved for use by others, including future generations. It takes a certain maturity or breadth of perspective to appreciate the common good which flows from this kind of regulation, and at least the initial reaction to its imposition is likely to be hostility. In this sense the current rebellion once again shows how history tends toward repetition, since earlier efforts to strip the federal goverment of much of its remaining land holdings were also sparked by increasing federal regulation. ${ }^{\text {et }}$

Another factor which explains why the rebellion has advanced as far as it has and as fast as it has is the lag between demographic changes and political power shifts. Many are surprised to learn that the modern West has become, by generally accepted standards of measurement, the most urban region in the

os The BLM recently estimated that, in 1979 , there were more than 200 million "visitor days" for recreation use on the public lands. U.S. DEP'T OP THE INTERIOR, Press Release, at 2 (Jan. 7, 1981). The Ixplosion of these non-traditional uses in recent years brings to mind Frank Lloyd Wright's prediction of Arizona's future, announced in 1957:

Arizona, youngest of the United States, is also youngest in geologic time. Therefore outlines are sharpest and most colorful, contours are most picturesque. Her terrain is unique in the world; destined, in spite of the obtuse insistence upon industry and agriculture, to become the playground of these United States of America.

F.L. Wright, Plan for Arizona State Capitol, Oasis, Scottsdale, Ariz., Feb. 17, 1957, quoted in D. Mann, The Politics of Water in Arizona 75 (1963). This vision-discounting Wright's exaggerated willingness to disregard other values-might fairly be applied to the West as a whole. Wright appears, however, to have missed the mark in one respect. Rapidly increasing foreign tourism in the West suggests that the region may become a playground of the world.

of See notes 13 \& 85 supra. 
country. ${ }^{95}$ The availability of nearby public lands for recreation and the value that open spaces provide the human spirit are important parts of the lifestyle that most Westerners lead from their urban oases. Recreation and tourism are major sectors in the economies of most Western states, sometimes even outstripping more traditional pursuits such as mining, grazing and farming. ${ }^{96}$ But in many areas of the West, the interests of urbanites and suburbanites have not yet been effectively translated into political power in state legislatures. Where public lands are concerned, traditional agricultural, stock-raising and mining interests still tend to hold sway, though the situation is changing. ${ }^{97}$

Related to this lag in the shift of political power is the generally perceived weakness in the rebels' legal claim, for the rebels' political case in the state legislatures might well have been considerably weaker if their legal case had been stronger. Many may have voted for the bills not so much out of belief in the wisdom

-5 For example, using the older Census Bureau definition of urban as basically those areas of 2,500 inhabitants or more, in 1940 only one of the eleven Rocky Mountain and Pacific states (California) had a percentage of urban population above the national average. BuREaU of THE Census, U.S. DEP'T OF CoMmerce, Statistical Abstract of the United States: 1950, at 41. By 1960, five of these states (Arizona, California, Colorado, Nevada and Utah) were above the national average. Bureau of the Census, U.S. Dep't of Commerce, StatisTiCal ABstract of THE UNITEd STates: 1962, at 20. Using the newer metropolitan area population index (those inhabitants of standard metropolitan statistical areas embracing a core city of 50,000 or more), those same five states had a higher percentage of metropolitan area population than the national average in 1977. Bureau of the Census, U.S. Dep't of Commerce, Statistical Abstract of THE UNITED STATES: 1979, at 19. And looking at the West as a whole, in 1970 $82.9 \%$ of the people in the West were urban, compared to a national average of $73.5 \%$, and to figures for the northeast, north central and south of $80.4 \%$, 71.5\% and $64.6 \%$, respectively. Bureau of the Census, U.S. Dep'T or Commerce, County and City Data Book 1977, at 2.

- To some extent, of course, use of the public lands for recreation, especially off-road vehicle use, may be restricted by federal regulation called for by the FLPMA. Ultimately, however, such regulations are designed to protect recreational uses of the public lands, by ensuring long-term maintenance of the qualities which bring recreationists there in the first place.

${ }^{97}$ See generally D. Mann, The Political Implications of Migration to the Arid Lands of the United States, 9 Nat. Resources J. 212 (1969). Professor Mann described the legislatures of the arid region states as tending "to be dominated by conservatives who have not recognized the rapidly expanding needs of urban populations." Id. at 222 . He also described the states' administrative structures as "clumsy and disjointed, especially with regard to the management of natural resources." Id. 
of the program to transfer lands out of federal ownership, but more because the measure was a legally ineffective, and therefore harmless, gesture of displeasure against Washington.

Finally, the rebellion partakes of the current movement to return to states and localities greater responsibility over their affairs. While that movement extends far beyond federal land management policies, it has certainly been felt in that area. ${ }^{88}$ It is interesting to note that the sagebrush rebellion reached a flash point before a major reform embodied in the FLPMAsystematic planning for the uses of the public lands and their resources-was given a real chance to work. This is both ironic and unfortunate, because one aspect of this congressionally mandated land-use planning process has been almost wholly ignored in the sagebrush rebellion debate. Specifically, it can be argued that the FLPMA gives state and local governments a much greater say in federal land management than previously. The land-use planning provisions of the FLPMA require the BLM to coordinate public land-use planning with the planning and management programs of the states and local governments within which such lands are located. ${ }^{90}$ This coordination includes mandatory consideration of state and local plans, "mean-

${ }^{93}$ Over the past decade or more, the locus of some federal land management decision-making was transferred from field and regional offices to Washington. This shift was largely a response to demands for reform of federal management policies and the need to devise a consistent response to new congressional acts such as the FLPMA. But these changes have now largely been formulated, and responsibility for their implementation and general decision-making authority is once again returning to the field. To take one example, the old system under which federal coal leasing was administered in the field was halted by Secretary of the Interior Rogers Morton in 1971, who responded to criticism that it was inadequate for, among other things, failing to take proper account of other possible uses of federal coal lands and environmental protection. After several years of false starts toward devising a better system-congressional reform of the coal leasing laws and enactment of a federal surface mining reclamation law-a new program was put in place by Secretary Andrus in 1979. Responsibility for implementing the new program, which has attracted fairly widespread support, especially from affected state and local governments, will once again be largely in the field. See Krulitz, Management of Federal Coal Reserves, 24 Rocky MT. Min. L. INst. 139 (1978); Watson, The Federal Coal Follies, 58 Denver L.J. 65 (1980). But see Note, Managing Federal Lands: Replacing the Multiple Use System, 82 YALE L.J. 787 (1973) (the delegation of federal land management decision-making authority to the local level favors local commercial users over recreation and conservation interests).

43 U.S.C. § 1712(c)(9) (1976). 
ingful public involvement" by state and local government officials, mandatory consistency of federal with state and local plans "to the maximum extent [the Secretary] finds consistent with Federal law and the purposes of this Act," and resolution of inconsistencies between federal and non-federal plans "to the extent practical."100 While Congress stopped short of giving nonfederal governments veto power over federal plans, ${ }^{101}$ it signifcantly enlarged the formal opportunities for state and local influence over federal management. ${ }^{102}$ It would be unfortunate if the rebellion continues to deflect attention away from this cooperative process embodied in the FLPMA; in this sense, at least, the rebellion is, in Utah Governor Matheson's words, a "diversion" in the states' effort to influence federal lands decisions. ${ }^{108}$

Given these disparate factors, I believe that the sagebrush rebellion will ultimately be viewed as representing not the beginnings of a second American Revolution, but instead a last gasp of a passing era, a poignant effort to turn back the clock to the days when competition among uses of federal lands was rare, when resources seemed inexhaustible, and when a consensus existed for exploitation. Yet there are reasons to welcome it. For one thing, it will focus attention on positive as well as negative attributes of federal land ownership, out of which may ultimately emerge an even stronger consensus for sound land management. Although concern about such management and support for federal land managers exists, it is often latent. A frontal assault like the sagebrush rebellion can be the catalyst to mobilize it. Those calling for state or private ownership will, I would suggest, ultimately find that they are a minority - that the public lands have friends and supporters in numbers greater than

${ }^{200}$ Id. The BLM has implemented this requirement in its land-use planning regulations, see, e.g., 43 C.F.R. \$§ 1601.4-1, -3 (1979), and recently proposed amendments to clarify the consistency provisions. See 45 Fed. Reg. 82,679 (1980).

${ }^{101}$ Conference Comm. Rep., H.R. Rep. No. 94-1724, 94th Cong. 2d Sess. 58 (1976).

102 Compare the FLPMA provisions with $\S 32$ of the Mineral Leasing Act of 1920 , 30 U.S.C. $\S 189$ (1976), as construed in Ventura County v. Gulf Oil Corp., 601 F.2d 1080 (9th Cir. 1979), aff'd mem., 445 U.S. 947 (1980). See also Percival, State and Local Control of Energy Development on the Public Lands, 32 Stan. L. Rev. 373, 380-90 (1980).

103 Address at Utah Law Review Annual Banquet (Feb. 16, 1980), quoted in 1980 UTAH L. REV., supra note 23, at 505. 
the rebels imagined. ${ }^{104}$ These supporters are not limited simply to effete eastern liberals but embrace many of diverse political persuasions in the West as well. ${ }^{105}$ If $I$ am correct in surmising that these people constitute a large, if largely silent, majority, their organization around the sagebrush rebellion could prove to be a powerful force indeed.

Another positive effect of the sagebrush rebellion may well be a sharpened focus on state management of state-owned lands. In contrast to their frank call for transfer of public lands out of federal ownership, the rebels have been somewhat vague about how the land would be handled once the states took over. ${ }^{100}$ Some rebels appear to favor transfer into private ownership, while others seem to believe that the states should retain ownership and manage the lands for multiple uses as the federal government now does. ${ }^{107}$ The debate should, then, logically lead to a

104 Even some who initially support the rebellion might have second thoughts if large-scale transfers become a real possibility. Miners, for example, pay no royalty to the federal government in extracting minerals under the Mining Law of 1872 , ch. 152, 17 Stat. 91 (codified in scattered sections of 30 U.S.C.), whereas that would not always be true if the lands were in state or private hands; for example, some states lease minerals with a royalty payment. See, e.g., Ariz. Rev. Stat. AnN. §§ 27-231 to -238 (1976); Wyo. Stat. § 36-6-101 (1977). Similarly, graziers currently pay less than market value to graze the public lands under § 6(a) of the Public Rangelands Improvement Act of 1978, 43 U.S.C. § 1905 (Supp. III 1979); legislative history reprinted in [1978] U.S. Code Cong. \& AD. News 4069, 4074-75, which might also be jeopardized if the lands were transferred out of federal ownership.

${ }^{105}$ The voters in the State of Washington recently rejected by a substantial majority a state constitutional amendment inspired by the rebellion. See note 52 supra.

${ }^{100}$ See sources cited in note 6 supra.

107 In this connection it should be noted that some Western states are under constitutional or statutory mandates to manage state lands to achieve maximum dollar return. See, e.g., State ex rel. Powning v. Jones, 21 Nev. 510, 517; 34 P. 450, 453 (1893); Wyo. Const. art. 18, § 3; Colo. Const. art. IX, § 10. One curious, but welcome, result of the sagebrush rebellion is that some of those states laying legal claim to federal lands have, in the process of doing so, revised their state land-management laws to call for more balanced multiple uses without the straitjacket mandate of maximum economic return. See, e.g., NEv. REv. Stat. § 321.5977, added by ch. 1365, 1979 Nev. Stats. 1362; N.M. STat. ANN. 19-15-2 (Supp. 1980). Whether such revisions are consistent with the federal trust conditions on such lands is beyond the scope of this article. See note 21 supra. The Public Land Law Review Commission recommended outright abolition of such restrictions. PLLRC REPORT, supra note 18, at 247-48. 
closer scrutiny of current state land-management programs, ${ }^{108}$ as well as an examination of the broader issue of private versus government control. ${ }^{109}$ It may, in other words, explore whether it

${ }^{108}$ Large acreages are owned and managed by the Western states, e.g., nearly ten million acres in Arizona, Arizona State Land Dep'r, Arizona State Land Management, 1978-79 AnN. Rep. 5-1, nearly four million acres in Utah, Utah Div. of State Lands \& Forestry, 1978-79 Ann. Rep. 24, and nearly three million acres in Washington, Washington Dep'T of Natural Resources, Resource Management Information (July 1980). Since the rise of the sagebrush rebellion, one study of state versus federal land management has emerged. Utah Agricultural Experiment Station, An Economic Evaluation of the Transfer of Federal Lands in Utah to State Ownership (May 1980). This study focuses on economic returns from public land resources and comparative state and federal land-management costs. While such factors are undeniably relevant to any comparative evaluation of state and federal management, they may not tell the whole story. Perhaps state land management is cheaper, but it may be only because state information-gathering and planning are more cursory and because state land managers are paid less and are individually responsible for larger tracts of land than their federal counterparts. Higher salaries, greater information-gathering and more intensive planning do not necessarily spell better management, but they should be part of the equation.

Just as lower management costs do not in and of themselves show better management, neither does a high direct economic return. Multiple-use management does not, as Congress has repeatedly recognized, "necessarily [mean] the combination of uses that will give the greatest economic return or the greatest unit output." 43 U.S.C. § 1702(c) (1976). See also 16 U.S.C. § 471 (1976). Certain values of the public lands stubbornly defy economic quantification or yield to it only with difficulty. In particular, those values springing from management for fish and wildlife habitat and aesthetics may be roughly calculated in terms of tourism and recreation, including sport-fishing and hunting, but such an analysis tells only part of the story. See, e.g., J. KrutiLlA \& A. Fisher, The Economics of Natural Environments: Studies in The Valuation of Commodity AND Amenity Resources (1975). Given these difficulties, I suspect that purely statistical analyses of federal versus state land management will result in conclusions which, although satisfying the predilections of the analyst, are subject to challenge on a variety of grounds. Nevertheless, if the sagebrush rebellion prompts closer scrutiny of how states manage their lands as compared to the federal government, it should advance more widespread understanding of what factors make for good land management.

109 To the extent that the rebels call for transfer into private ownership, the problem of evaluating comparative management becomes more difficult. Private ownership may mean more tax revenues to state and local government, but then again it may not. The Payments in Lieu of Taxes Act, 31 U.S.C. §§ 1601-1607 (1976), is explicitly designed to compensate such governments for tax revenue "lost" as a result of federal ownership, and a multiplicity of other federal acts contain mechanisms for sharing the revenues derived from exploitation of federal lands and their resources with state and local governments. For a useful if somewhat outdated summary of revenue sharing schemes 
is federal management or public ownership which causes the problems the rebels perceive.

The rebellion might also prompt a reexamination of federal financial assistance to those states with large amounts of federal lands, including the wisdom of continuing the heavy subsidies for western agriculture embodied in the federal reclamation program, ${ }^{110}$ the special "revenue sharing" of the Payments in Lieu of Taxes Act," 111 and the existing schemes for sharing with the states the revenues generated from the sale and lease of federal

involving the public lands, see Table I in Muys, A View of the PLLRC Report's Recommendations Concerning Finances, 6 LAND \& WaTER L. REv. 411, 420-25 (1970). Whether these devices adequately compensate, or overcompensate, state and local governments for the "penalty" of federal ownership would be difficult to calculate and may indicate, more than anything else, the predilections of the analyst. Here, too, purely fiscal calculations are deficient. Transfer of public lands into private ownership may limit or even eliminate access to those lands for recreation and other uses whose economic benefits are imponderable, or at least difficult to calculate, even as they open up such lands to greater exploitation of other resources, such as forage and minerals, that more readily yield to such an evaluation. But once again such a debate is welcome if it leads to greater appreciation of what governmental, as opposed to private, management of these land means. See Udall, The West and its Public Land-Aid or Obstacle to Progress, 4 Nat. Resources J. 1 (1964).

${ }^{110}$ Several special programs for the Western states adopted several decades ago still survive, including the Desert Land Act, the Carey Act and the federal reclamation program. See note 17 supra and P. GATES, supra note 8, at 635-98. The principal reason Congress enacted these programs was to promote Western migration and settlement. Population trends suggest that this objective need no longer be a focus of national policy, and consequently continuing the subsidies of the reclamation program has been criticized. For example, the congressionally-created National Water Commission recommended their elimination in all new projects. U.S. Nat'l Water Comm'n, Water Policies por the Future-Final Rep. 485-99 (1973). See also Common Cause, The GovernMENT Subsidy SQuzeze 42-43, 53-56 (1980); P. Gates, supra note 8, at 681-97; Leveen, Reclamation Policy at a Crossroads, 19 Bull. Inst. Gov'tal Studirs, No. 5 (U. of Cal., Berkeley) (Oct. 1978).

The connection between the federal reclamation program and federal retention of lands after statehood was underscored by Utah Governor Dern while testifying about the 1930 proposal to cede the unappropriated public lands to the Western states: "The extension of agricultural development in the Western States is dependent upon reclamation works built by the Federal Government. . . . [W]e do not want to take that power [of the federal government to build such projects] away by accepting these public lands." $H$. Public Lands Hearings, supra note 12, at 16.

111 See note 109 supra. 
lands and resources. ${ }^{112}$ Because the theory on which the rebels seek transfer of federal lands is bottomed on equity, the rebellion inevitably implicates questions of fairness among regions in the distribution of federal benefits, as well as the ownership of federal lands. Such questions have recently surfaced in federal water project funding, ${ }^{113}$ and ongoing efforts to bring the federal budget into balance might well make this a propitious time for scrutiny of such federal programs. If such an examination shows that the states with large amounts of federal land obtain more federal funds than other states, of course, the rebels' case is weakened. Measurements that are readily available, while admittedly crude, might give the rebels pause. ${ }^{114}$

Finally, I am not so enamored of federal ownership that I will admit to the infallibility of federal land management. Certainly there are ways in which federal red tape can be cut and federal

112 Id.

118 For example, the New England Regional Commission recently estimated that, between 1950 and 1975 , the West received $\$ 377$ per capita in federal water supply program funds, while the Northeast received only $\$ 47$ per capita. 11 Envir. ReP. (BNA) 929-30 (Oct. 24, 1980). Senators Domenici of New Mexico and Moynihan of New York have introduced legislation to distribute federal water supply funds nationwide to each state on an area and population formula, rather than on an individual project basis. Amendment 1660 to S.703, 96th Cong., 2d Sess., 126 Cong. Rec. 1256 (1980). Also relevant here is the turn-of-the-century controversy surrounding establishment of a federal program to purchase cutover timber land in the East. The program was authorized by the Weeks Act of 1911, ch. 186, 36 Stat. 961 (codified in scattered sections of 16 U.S.C.), over the opposition of some in the West who wanted federal resource-management dollars to be spent on developing the water and other resources of the West. See S. Dana \& S. FaIrfax, supra note 13, at 111.

114 Councll of State Governments, The Book of The States 1980-81 Table 5 , at 303 (1980), lists the federal contribution to state general revenues, per capita for each state, based on Bureau of the Census statistics. The national average is $\$ 319$ per capita in federal aid, but of the six "rebel states," only Arizona and Washington fall below that. Wyoming ranks third nationally, New Mexico eighth, Nevada fourteenth and Utah seventeenth. The top six also include Alaska, Montana and Oregon. Former Secretary of the Interior Stewart Udall, himself a Westerner, several years ago warned the West of the dangers of fighting this battle: "Over the years, the flow of funds westward from Washington has been heavier proportionately than to any other region of the United States." Udall, supra note 109, at 15. See also Mann, supra note 97, at 215. More recently, Utah Governor Matheson has stated that federal policies have not "severely restricted development options" or "stifled economic growth," at least in his state. Address at Utah Law Review Annual Banquet (Feb. 16, 1980), quoted in 1980 UTAH L. REv., supra note 23, at 512, n.47. 
decision-making made more sensitive to local concerns, without sacrificing the national interest in proper management of these lands. There also must be situations in which the public interest might well dictate the sale or exchange of federal lands. ${ }^{115}$ To the extent that the sagebrush rebellion represents public dismay at genuinely insensitive and misguided federal attitudes, it may well succeed in enhancing the federal government's appreciation of state and local concerns.

\section{Conclusion}

As constitutional theory, the sagebrush rebellion is fatally flawed. The rebels are surely fighting the wrong battle-for absolute ownership of all public lands rather than for more limited transfers and a greater state and local voice in federal land management. And they are fighting in the wrong place-the courts rather than in Congress and the executive land-management agencies.

Despite its legal veneer, the rebellion is, like its predecessors, a political movement. Accepting it as such, as raising questions about federal, and indeed all governmental land management, the rebellion is not wholly undesirable. I suspect, however, that the ultimate outcome will be largely counter to the rebels' objective, even though the results of the recent national election have been hailed by the rebels as paving the way for ultimate victory. ${ }^{116}$ Whatever November 4 th was a mandate for, I would ar-

115 One particularly creative illustration of this is recent legislation, fashioned jointly by California Congressman Phillip Burton and Nevada Congressman Santini, which authorizes the sale of BLM-managed land in the Las Vegas urban area, with part of the proceeds employed to acquire unimproved land in environmentally sensitive areas around Lake Tahoe. Act of Dec. 23, 1980, Pub. L. No. 96-580, 94 Stat. 3381.

Utah's Governor Matheson has recently proposed large-scale exchanges of scattered state school sections for larger blocks of federal land, as a "solution" to the sagebrush rebellion. Arizona Republic, Feb. 14, 1981, at A-1, col. 3. While not a solution to those rebels seeking outright transfers of federal lands rather than exchanges, blocking up larger tracts of state and federal land would allow for more coherent management by both the federal government and the respective states by eliminating pesky problems associated with isolated inholdings, such as difficulty in assembling economically attractive development units and access problems. The problem with effecting such exchanges has always been determining equal value for the parcels exchanged.

116 President Reagan was widely quoted as supporting the rebellion during his campaign. See Boly, supra note 6 , at 17 . A week after the election, the 
gue it was not to strip the national government of ownership of large areas of public lands. ${ }^{117}$ Instead the rebellion will likely bring forth greater appreciation and stronger support for federal land managers as they go about the increasingly difficult task of balancing competing demands upon the public lands and their resources. ${ }^{118}$

President's campaign manager, Senator Laxalt of Nevada, affirmed that the new Administration would indeed support the rebellion to return some 700 million acres of Western lands now held by the federal government to the Western states. Arizona Republic, Nov. 11, 1980, at A-11. Shortly after the election, the President himself sent a telegram to a rebel conclave in Salt Lake City in which he once again described himself as a "Sagebrush rebel," and pledged his support for a "Sagebrush solution," which he somewhat opaquely described as one which would "ensure" that the states have an "equitable share of public lands and their natural resources." Arizona Republic, Nov. 21, 1980 , at A-12.

117 For example, the voters of the State of Washington, whose legislature had enacted a sagebrush rebellion statute, resoundingly defeated a proposed amendment to the state constitution laying claim to federal public lands at the same time they supported President Reagan and elected a new Republican senator and governor. See note 52 supra.

118 Once again history might provide a clue to the current rebellion's ultimate outcome. Just two years after a major administration-backed effort to transfer public lands to the states, see notes $12,13,80$ \& 85 supra, Congress enacted the Taylor Grazing Act, Act of June 28, 1934, ch. 865, 48 Stat. 1269 (codified in scattered sections of 43 U.S.C.), which tightened federal control over the unappropriated public domain and de facto if not de jure ended the era of large-scale disposition of the public lands. See PLLRC REPORT, supra note 18 , at 28 . 
Heinonline -- 14 U.C. Davis L. Rev. 356 1980-1981 